\title{
O GRAFEMSKIM OBILJEŽJIMA NA PRIMJERIMA VELIKOGA POČETNOG I POSEBNIH TIPOVA SLOVA U SLUŽBENOM DOPISIVANJU
}

\author{
Ivana Nardelli Debač \\ Ministarstvo vanjskih i europskih poslova
}

\begin{abstract}
Pregled suvremenih istraživanja grafema pokazuje raznolikost pristupa samom pojmu, što nerijetko otežava njegovu cjelovitu i jasnu definiciju. U radu su grafemska obilježja terminološki istovrijedna slovnima kako bi se na primjerima velikoga početnog i posebnih tipova slova (kosih i podebljanih) provjerilo na koje načine grafem/slovo može biti pokazatelj komunikacijskih namjera pošiljatelja. Prikupljena je građa iz službenoga pisanog diskursa i provedena je dvorazinska kontrastivna analiza primjera na hrvatskome $i$ engleskome jeziku. Prvom razinom analize utvrđene su sličnosti i razlike između normiranih oblika upotrebe navedenih tipova slova u oba jezika, a njihov usustavljeni prikaz poslužio je kao polazište za ispitivanje pretpostavke da će se u službenoj uporabi javiti povremena odstupanja od norme najviše zahvaljujući utjecaju engleskoga jezika. Međutim, drugom razinom analize utvrđeno je da navedena odstupanja ponajviše ovise o kontekstu i namjerama autora službenih pismena. Grafemska obilježja, kao što su veličina i oblik slova, na jednostavan i ekonomičan način služe isticanju podataka važnih za određeno administrativno okružje.
\end{abstract}

Ključne riječi: grafem, obilježja, slova, službena komunikacija, jezična uporaba

\section{UVOD - O SLIČNOSTIMA I RAZLIKAMA POJMOVA GRAFEM I SLOVO}

Od samih početaka nastanka pojma grafem pa sve do danas postoje i njegova različita određenja, ovisno o tome definiramo li grafem prema pojmu fonem ili njime želimo označiti pojam slova. "Grafem se često rabi kao istoznačnica nazivu slovo, u hrvatskomu i u drugim jezicima gdje se rabe istovrijednice. Pri tomu je riječ slovo domaći, a grafem međunarodni stručni naziv. Sama je riječ grafem višeznačnica, $u$ širem značenju predstavlja najmanju grafičku jedinicu sustava pisanja nekoga jezika, u nešto užem najmanji razlikovni znak nekoga sustava pisanja. Kroatisti nazive grafem i slovo znaju rabiti u istome tekstu kao istoznačnice." (Jelaska i Musulin, 2011: 217-218). Naziv grafem među prvima je počeo upotrebljavati Baudouin de Courtenay (1972) koji je nalazio povezanost pojmova grafem i fonem u smislu da oba predstavljaju mentalne slike u umu govornika. Marković (2015: 79) ističe da je Baudouin 
de Courtenay (1972), u stvari, prvi definirao grafem kao „najjednostavniji element pisma“, odnosno "najjednostavniju grafičko-optičku predodžbu povezanu s čitavim slovom".

Strukturalistički pristup pojmu grafema uz dihotomiju grafem:fonem zadržao se sve do danas, što je posebice vidljivo u tvrdnji Markovića (2015: 77) da "grafema u pojedinom alfabetskom pismovnom sustavu ima onoliko koliko u jeziku koji se njime bilježi ima fonema".

No, potrebno je odmah istaknuti da je ta tvrdnja relevantna za istraživanja, između ostaloga i za ovaj rad, koja se bave samo alfabetskim sustavima pisanja gdje je "grafem istovrijednica slovu“ (Pulgram, 1976: 3).

Badurina (2012: 70) upozorava na nedosljednost u razdiobi pojmova slovo i grafem prema dostupnoj literaturi: po jednom tumačenju, slovo je znak za fonem, a grafem je jedinica grafijskog sustava, dok po drugom tumačenju, fonemima odgovaraju grafemi, koji mogu biti jednoslovi, dvoslovi ili troslovi. Smatramo da se različita terminološka tumačenja slova i grafema javljaju i javljat će se jer u suvremenim alfabetskim sustavima pisanja ne postoji apsolutna usklađenost grafema i fonema. Najbliže objašnjenje tomu može se primjerice naći kod Pulgrama (1976: 7) koji drži da se navedena usklađenost ne uspijeva ostvariti jer moderni pismovni sustavi upotrebljavaju pisma koja nisu izvorno bila namijenjena njihovim jezicima, kao što je latinski alfabet. Drugo i šire objašnjenje mogućih neusklađenosti pojmova slova kao ostvaraja fonema i grafema kao konkretnog ostvaraja u tisku leži u primarnoj razlici između govorenoga i pisanoga jezika, na koju je stavio naglasak i Daniels (1996: 3-4) zabilježivši da se za mnoga obilježja fonema ne mogu pronaći istovrijedna obilježja grafema i obrnuto.

Uzimajući u obzir navedena tumačenja odnosa grafema i fonema te posebice grafema i slova, $u$ radu se polazi od teze da se fonemskim obilježjima ne mogu izraziti pojedine nijanse u pridavanju važnosti određenim riječima i skupovima riječi koje je moguće iskazati grafemskim značajkama kao što su veličina i oblik slova, u slučajevima kada je grafem istovrijednica slovu. Stoga će istraživanje $u$ radu biti provedeno u jezicima s fonološkim pismima, tj. alfabetima hrvatskoga i engleskoga jezika gdje će grafemska obilježja biti istovjetna slovnima te će se ispitivati funkcija velikoga početnoga i posebnih tipova slova u razlikovanju značenjskih nijansi pojedinih pojmova koji su ustaljeni $u$ administrativnoj praksi.

\section{TEORIJSKA POLAZIŠTA ZA ISTRAŽIVANJE}

U uvodu je dana kratka definicija grafema, a za potrebe rada grafem je izjednačen sa slovom.

Kako bi se bolje obrazložilo takvo terminološko određenje, potrebno je dati kratki prikaz problema u prijašnjim istraživanjima grafema kao funkcionalne razlikovne jedinice u pisanju. 
$\mathrm{Na}$ početku je važno naglasiti da je naziv grafem nastao „u zapadnoeuropsko-mediteranskom okrilju jezika koji se bilježe alfabetskim pismom" (Marković, 2015: 80) pa se pod nazivom slovo podrazumijevaju slova abecednog pisma. Jedno od osnovnih obilježja abecednog pisma jest jednostavnost upotrebe jer se uz pomoć ograničenog broja jedinica omogućava prijenos praktički neograničenog broja sadržaja iz apstraktne jezične strukture u našem umu (Catach, 1986: 2). Upravo je ta komunikacijska funkcija abecednog pisma važna za temu rada budući da se istraživanje provodi na građi nastaloj u uvjetima službene komunikacije koju odlikuje brzi prijenos relevantnih podataka za primatelje.

Ako se promotri povijest nastanka abecednog pisma kao svojevrsna prilagodba pisanih simbola govornima, može se uočiti da su sve do kraja 19. stoljeća u jezičnom opisu korišteni pojmovi slovo i glas. Chao (1961: 71) ističe da su ti pojmovi ponajprije vezani uz korištenje latinskoga alfabeta gdje je najnormalnije da ljudi govore o glasovima ili slovima o ili $e$, dok je za nekog tko piše logografskim sustavom poput kineskoga, "standardni i uobičajeni“ alfabet krajnje apstraktan.

Augst (1986: 29) se slaže da su to „zdravorazumski“ pojmovi u svakodnevnom jeziku, međutim za jasnu i preciznu jezikoslovnu teoriju potrebno je ustanoviti pojmove kao što su fonem, grafem, fon i graf. Nadalje, Augst (1986: 27) tvrdi da glasovi ne odgovaraju slovima, već fonemi grafemima, a njihov odnos prikazuje uz pomoć sljedeće sheme kao u (a).

(a)

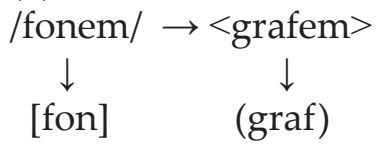

Na istom tragu, odnos fonema i grafema objašnjava i Marković (2015: 81) te drži da je više nego poželjno izgraditi gramatološku terminologiju koja će što više odgovarati fonološkoj: "Ako u fonologiji imamo foneme i fonove, imajmo u gramatologiji grafeme i grafove."

Ovdje valja napomenuti da se fonem i grafem promatraju kao apstraktne jedinice, a fon i graf kao njihovi konkretni ostvaraji. Budući da glasovni sustav nema ništa slično malim i velikim slovima, postavlja se pitanje jesu li primjerice $A$ i $a$ dva različita grafema ili alografi jednoga (Musulin, 2011: 243). Marković (2015: 92-93) odgovara na tu dvojbu postavivši pravilo, analogno fonološkom, da se grafem $<<a>>$ ostvaruje kao graf $<\mathrm{A}>$ na početku rečenice i na početku vlastitih imenica, u svim drugim slučajevima ostvaruje se kao graf $<a>$. Smatra da su alografi jednoga grafema sve dotle dok se njima bilježi jedan te isti fonem, a uvjetovani su gramatološkim kontekstom. 
Ako, sukladno ranije uspostavljenom terminološkom izjednačavanju grafema i slova, jednako tako izjednačimo pojam alografa s malim i velikim slovom, $\mathrm{u}$ radu će se istražiti primjeri pisanja velikoga početnog slova $\mathrm{u}$ službenoj komunikaciji gdje se ne primjenjuje gore navedeno pravilo, već je upotreba velikoga početnog slova ili grafa $<\mathrm{A}>$ uvjetovana drugačijim gramatološkim kontekstom.

Takvoj pretpostavci u prilog ide tvrdnja Jelaske i Musulin (2011: 219) prema kojoj raspodjela grafova može biti obavezna, kao npr. u pisanju velikoga početnoga slova na početku rečenice, a može biti i slobodna što onda povlači zaključke o višeznačnim obilježjima alografa, tj. malog i velikog slova. Primjerice, prema Gallmannu (1986: 50) malo i veliko početno slovo predstavljaju paradigmu s dvije različite funkcije te se jednako tako mogu promatrati kao dva zasebna, ali funkcionalno povezana grafema.

Osim navedenih autora (Jelaska i Musulin, 2011; Marković, 2015; Musulin, 2011), u hrvatskoj znanstvenoj literaturi postoji vrlo mali broj radova u kojima su se jezikoslovci bavili funkcijama i značenjskim obilježjima grafema. Radovi iz područja normativne lingvistike i standardizacije hrvatskoga jezika ${ }^{1}$, kao što je ranije ustanovljeno, grafem rabe u značenju slova, a takvo terminološko određenje primijenit će se i u ovom članku. U stranoj literaturi valja izdvojiti rad McAteer (1992) kojim se po prvi put ispituju grafijska rješenja u smislu upotrebe velikoga početnog i kosih slova da bi se naglasila obavijesna važnost pojedinih riječi, što predstavlja polazišnu osnovu za analizu u ovom radu.

\section{CILJ RADA}

Cilj je rada dvorazinskom kontrastivnom analizom usporediti hrvatska i engleska pravopisna pravila, kao i primjere upotrebe velikoga početnog i posebnih tipova slova kako bi se pokazale podudarnosti i razlike njihovih grafemskih obilježja te ujedno provjerilo unose li ta obilježja dodatnu jezičnu vrijednost u suvremeni sustav službene komunikacije. Istraživačka se pitanja stoga odnose na mogući utjecaj engleskoga jezika na pravopisna pravila hrvatskoga jezika, čime se želi provjeriti hoće li se javiti odstupanja od norme i ako se javljaju, radi li se o prilagodbi pravopisnih pravila posebnostima službenih oblika komunikacije. U vezi s tim posebno je važno ispitati suodnos najmanjih jedinica pisanog i govorenog jezika pa će se razmotriti pojedini slučajevi u službenoj komunikaciji kada pošiljatelj primatelju želi skrenuti pozornost na obavijesno važne dijelove pisanog akta. U navedenim slučajevima polazi se od hipoteze da se određeni broj primjera upotrebe velikoga početnog i posebnih tipova slova u hrvatskome

\footnotetext{
1 Više v. u Babić i dr. (2007), Badurina (2006), Barić i dr. (2005), Jelaska (2004), Marković (2014), Mesaroš (1971), Mihaljević (1991), Silić i Pranjković (2005), Težak i Babić (2007), Turk (2002).
} 
jeziku oslanja na grafemska/grafijska rješenja engleskog administrativnog stila. Druga je pretpostavka da autori teksta žele naglasiti važnost pojedinih riječi ili rečeničnih cjelina te ih stoga pišu velikim početnim slovom ili ih ističu posebnim tipovima slova.

\section{METODOLOGIJA RADA}

Osnovni metodološki preduvjet za analizu jest prethodno razmatranje pravila koja se dotiču specifičnosti administrativnoga stila uz naznaku da će se pobliže objasniti uloga velikoga početnog i posebnih tipova slova u grafemskome/grafijskome sustavu službene prakse.

Uzme li se u obzir pretpostavka da upotreba tih slova predstavlja svojevrsnu jezičnu univerzalnost $u$ suvremenim alfabetskim sustavima, kontrastivna analiza nameće se kao učinkovita metoda provjere kojoj nije svrha tek puka usporedba već pronalaženje jezičnih univerzalnosti s ciljem utvrđivanja jezične ekonomije.

Prva razina kontrastivne analize $u$ radu obavit će se supostavljanjem normiranih oblika upotrebe velikoga početnog i posebnih tipova slova $\mathrm{u}$ hrvatskome i engleskome jeziku kako bi se utvrdile sličnosti i razlike. Naime, prema Jamesu (1980) nerazumno je očekivati od svakog lingvista da provjeri potencijalnu jezičnu univerzalnost uzimajući u obzir sve svjetske jezike, najviše što može učiniti jest da prikupi potvrdne dokaze iz još jednog ili dvaju jezika kojima vlada. U ovom slučaju, to je engleski jezik.

Druga razina analize obuhvaća primjere u hrvatskoj i engleskoj službenoj praksi, gdje će se uspoređivati sličnosti i razlike u upotrebi velikoga početnog i posebnih tipova slova.

Građa je prikupljena iz pismohrane Glavnog tajništva Ministarstva vanjskih i europskih poslova u razdoblju od početka ožujka 2016. do kraja travnja 2019. godine te je za potrebe ovoga rada odabran samo reprezentativan dio primjera. Kriteriji za odabir građe uključuju čestotnost pojavljivanja općih imenica napisanih velikim početnim slovom te ostalih riječi i skupova riječi napisanih posebnim tipovima slova, kao i specifičnost konteksta u kojem se odabrani primjeri javljaju u okviru administrativnog funkcionalnog stila.

Najveći broj tekstova odnosi se na službene dopise koji su e-poštom razmjenjivani između Ministarstva vanjskih i europskih poslova RH i ostalih tijela $\mathrm{i}$ institucija unutar RH te EU institucija, kao i pojedinih stranaka, dok se određeni broj tekstova odnosi na mrežne objave službenih dokumenata nastalih unutar RH i EU institucija. Popis pregledanih dokumenata na hrvatskome i engleskome jeziku nalazi se $\mathrm{u}$ privitku 1, a popis pregledanih dokumenata iz mrežnih izvora na hrvatskome i engleskome jeziku u privitku 2.

Za analizu primjera upotrebe velikoga početnog slova odabrane su opće imenice jer je procijenjeno da bi analiza ostalih vrsta riječi, kao što su npr. pridjevi, za potrebe članka bila preopširna. U tu svrhu izdvojeno je 25 općih 
imenica $^{2}$ (tablica 1) s razmjerno visokom čestotnošću pojavljivanja u službenoj komunikaciji, a nisu uzeti u obzir primjeri pojavnica kada se imenica nalazi na početku rečenice kako ne bi došlo do preklapanja s pravopisnim pravilom o pisanju velikoga početnog slova za taj položaj riječi.

Tablica 1. Broj potorda općih imenica odabranih za analizu

\begin{tabular}{|l|l|l|l|l|l|}
\hline Br. & Opće imenice & Broj potvrda hrWaC & Br. & Opće imenice & Broj potvrda hrWaC \\
\hline 1. & informacija & 365,046 & 13. & pravilnik & 69,193 \\
\hline 2. & izvješće & 104,293 & 14. & predsjednik/ca & $657,231 / 60,809$ \\
\hline 3. & ministar/rica & $273,388 / 32,641$ & 15. & prijedlog & 208,398 \\
\hline 4. & ministarstvo & 276,345 & 16. & program & 695,346 \\
\hline 5. & misija & 66,952 & 17. & promemorija & 336 \\
\hline 6. & nacrt & 25,954 & 18. & savjetnik/ca & $46,015 / 7,790$ \\
\hline 7. & načelnik/ca & $76,969 / 4,840$ & 19. & sektor & 107,549 \\
\hline 8. & natječaj & 135,842 & 20. & služba & 200,073 \\
\hline 9. & odjel & 128,712 & 21. & sporazum & 101,380 \\
\hline 10. & odluka & 421,433 & 22. & strategija & 88,075 \\
\hline 11. & plan & 336,329 & 23. & upitnik & 16,628 \\
\hline 12. & povjerenstvo & 74,593 & 24. & uprava & 304,981 \\
\hline & & & 25. & uredba & 20,070 \\
\hline
\end{tabular}

Pri analizi primjera na engleskom jeziku, pronađene su istovrijednice tih 25 imenica na engleskome te je provjereno jesu li napisane velikim početnim slovom u kontekstu službenoga dopisivanja.

\section{ANALIZA PRAVOPISA, RJEČNIKA I JEZIČNIH VODIČA}

Administrativni funkcionalni ili administrativno-poslovni stil (Silić i Pranjković, 2005: 378) obuhvaća područje državne uprave, politike, vojske, ekonomije, trgovine, industrije, diplomacije i ureda općenito pa se njime pišu službeni dopisi, odluke, zakoni, uredbe, pravilnici, molbe, žalbe, izvješća itd. (Frančić, Hudeček i Mihaljević, 2005: 252). Obilježava ga uredsko-poslovni rječnik i nazivlje struke obuhvaćene sadržajem, a zbog raznovrsnosti tekstova koji se njime pišu dijeli se na nekoliko podstilova: zakonodavnopravni (statuti, zakoni, ustavi, naredbe, odluke, rješenja), društveno-politički (rezolucije, povelje, deklaracije, referati, izjave), diplomatski (note, protokoli, memorandumi), poslovni i personalni podstil, a personalni se dalje može dijeliti na stil molbe, žalbe, životopisa, ankete, formulara itd. (Kovačević i Badurina, 2001: 480).

\footnotetext{
${ }_{2}$ Potvrde za čestotnost imenica u hrvatskoj građi preuzete su iz hrWaC-a (Croatian web corpus, http:// nlp.ffzg.hr/resources/corpora/hrwac/), pri čemu je za 15 primjera imenica potvrđeno više od 100000 pojavnica, a samo je kod jednog primjera broj pojavnica bio manji od 1000 (imenica promemorija). Možda nije nevažno navesti i podatak da je kod imenica koje označuju zvanje ili položaj zabilježen znatno manji broj pojavnica kad se navode u ženskom rodu.
} 
Osnovne su značajke administrativnoga stila jednostavnost, sažetost, izričitost, objektivnost, analitičnost te neobilježenost i usklađenost s normama hrvatskoga standardnog jezika. Stoga je logično očekivati da će se jezik tekstova pisanih tim stilom temeljiti na ustaljenim i zadanim pravilima na pravopisnoj razini, no autori (Blagus Bartolec, 2017; Ćužić, 2016) nerijetko uočavaju da administrativni stil karakteriziraju česta odstupanja od pravila standardnoga jezika te da dolazi do nepoštivanja pravopisne norme $\mathrm{u}$ pojedinim segmentima poslovnoga podstila. Čužić (2016: 361) navodi primjer upotrebe honorifika u službenim dopisima kada se zamjenice zbog iskazivanja počasti pišu velikim početnim slovom, pri čemu je naglasak stavljen na namjeru pošiljatelja poruke.

$\mathrm{U}$ radu se polazi od pretpostavke da se pojedina odstupanja od norme javljaju iz dva razloga: prvi je da se pravopisna pravila prilagođavaju, a katkada i podređuju određenim suvremenim obilježjima administrativnih podstilova, kao što je primjerice brzi prijenos informacija $u$ poslovnom svijetu, što nas dovodi do drugog razloga koji se odnosi na rastući utjecaj engleskoga jezika u hrvatskoj administrativnoj praksi. ${ }^{3}$ Pritom treba imati na umu da se način normiranja pravopisa u Hrvatskoj razlikuje od zemalja engleskoga govornog područja.

Naime, u Hrvatskoj su pravopisna pitanja uređena pravopisima, dok su u engleskome jeziku pitanja ispravnog pisanja uređena rječnicima za slovkanje, a pravopisnim znakovima, poput velikoga početnog i posebnih tipova slova, bave se jezični vodiči. U svrhu prikaza upotrebe velikoga početnog i posebnih tipova slova, za referentne izvore odabrani su sljedeći hrvatski pravopisi: Anić-Silićev Pravopis hrvatskoga jezika (2001), BabićMogušev Hrvatski pravopis: usklađen sa zaključcima Vijeća za normu hrvatskoga standardnoga jezika (2011), Badurina-Marković-Mićanovićev Hrvatski pravopis (2008), odnosno kraće Matičin pravopis i Hrvatski pravopis Instituta za hrvatski jezik i jezikoslovlje ili Pravopis IHJJ (2013). Za referentne izvore s engleskoga govornog područja poslužili su The Cambridge Guide to English Usage (Peters 2004), The Oxford Style Manual (ur. Ritter 2003) ili kraće OSM, The Chicago Manual of Style (2010) ili kraće CMS te mrežno izdanje OED-a, odnosno The Oxford English Dictionary (2019).

\subsection{Sličnosti $i$ razlike u upotrebi velikoga početnog slova u hrvatskome $i$ engleskome jeziku}

Na početku se može ustvrditi da u hrvatskome i engleskome jeziku postoji zajedničko pravilo o pisanju prve riječi u rečenici i vlastitih imena velikim početnim slovom. S druge strane, kad se govori o razlikama u upotrebi,

\footnotetext{
${ }^{3}$ Ulaskom Republike Hrvatske u Europsku uniju 2013. povećani su oblici poslovne komunikacije između državnih, javnih i ostalih institucija RH s institucijama i tijelima EU, kao i ostalim međunarodnim organizacijama, ponajprije na engleskome jeziku.
} 
primjera je jako mnogo u različitim jezičnim stilovima. Smatramo da za potrebe rasprave $u$ radu nije potrebno navoditi sva postojeća pravopisna pravila, već će se istaknuti pravopisni primjeri i iznimke od pravila koji su važni za temu rada. Zbog sustavnosti prikaza, takvi primjeri donose se $u$ sljedećem pregledu:

(1) nazivi ustanova, tijela, organizacija i sl.: Hrvatska matica iseljenika i Ministarstvo vanjskih i europskih poslova naspram Croatian Heritage Foundation i Ministry of Foreign and European Affairs

(2) nazivi službenih tekstova, dokumenata, zakona, propisa, odredaba, pravilnika i sl.: Zakon o sudjelovanju civilnih stručnjaka u medunarodnim misijama $i$ operacijama naspram Act on Engagement of Civilian Experts in International Missions and operations

(3) nazivi skupova, događanja, sportskih natjecanja i sl.: Svjetske igre mladih naspram World Youth Games

(4) imena ulica, trgova, avenija i sl.: Trg Nikole Šubića Zrinskog i Ulica grada Vukovara naspram Nikola Šubić Zrinski Square i Vukovarska Street

(5) ostali zemljopisni lokaliteti: Rt dobre nade naspram Cape of Good Hope.

Navedena pravila pokazuju da se kod višerječnih naziva u hrvatskome jeziku samo prva riječ piše velikim početnim slovom (ostale riječi pišu se velikim slovom jedino ako su vlastita imena), dok se u engleskome jeziku prva i sve ostale riječi (osim članova i prijedloga) pišu velikim početnim slovom. Međutim, valja naglasiti da su gornji primjeri višečlanih naziva navedeni $u$ jednini, dok se množinski oblici općih imenica koje nisu u službi vlastitih imena u hrvatskome pišu malim početnim slovom, a u engleskome se takvi oblici imenica, bez obzira na množinu, i dalje pišu velikim početnim slovom (Babić-Mogušev pravopis 2011, CMS 2010):

(6) vlade Republike Hrvatske i Republike Makedonije naspram Governments of the Republic of Croatia and of the Republic of Macedonia.

Osim toga, u hrvatskome se jeziku javljaju i određene iznimke koje se navode $u$ pojedinim pravopisima. Tako se primjerice veliko početno slovo upotrebljava kada se umjesto punoga naziva navodi samo najvažniji član višečlanog naziva (Anić-Silićev pravopis 2001, Matičin pravopis 2008):

(7) Filozofski fakultet - Diplomirala sam na Filozofskom.

Kada se pred skraćenim nazivom nalazi neka riječ koja ga određuje kao opći pojam, taj skraćeni naziv piše se malim početnim slovom (BabićMogušev pravopis 2011):

(8) vaš odbor; navedeno povjerenstvo.

Za razliku od toga, Pravopis IHJJ (2013) navodi da se u administrativnim tekstovima velikim početnim slovom piše skraćeno ime tijela kad je u tekstu već navedeno njegovo puno ime:

(9) Odbor; Povjerenstvo. 
Kada se radi o nazivima službenih dokumenata, Pravopis IHJJ (2013) ističe da se malim početnim slovom piše naziv dokumenta prije nego što postane službenim:

(10) Pripremljen je Nacrt prijedloga zakona o izmjenama i dopunama Kaznenoga zakona.

U Pravopisu IHJJ (2013) također se napominje da je pri dvojbi o tome treba li što pisati velikim ili malim početnim slovom, bolje upotrijebiti malo početno slovo u skladu s načelom da se riječi, osim onih koje su obuhvaćene pravilom o velikom početnom slovu, $u$ hrvatskome jeziku pišu malim početnim slovom.

Od ostalih pravopisnih pravila koja se odnose na upotrebu velikoga početnog slova, ovdje će se razmotriti još neka koja pokazuju različite primjere upotrebe $\mathrm{u}$ hrvatskome i engleskome jeziku:

(11) opće imenice iza kojih slijedi broj ili slovo kao oznaka nizanja: članak 2. stavak 3. naspram Article 2, Paragraph 3

(12) pridjevi izvedeni od vlastitih ili zemljopisnih imena: šekspirijanski i talijanski naspram Shakespearean i Italian

(13) opće imenice kojima se označava zanimanje, položaj ili titula kad stoje pred imenom: predsjednik Trump i ministar Marić naspram President Trump i Minister Marić

(14) kratice zvanja ili titula: prof. i mr. sc. naspram Prof. i MSc.

Potrebno je napomenuti da kod referentnih pravopisa ne postoji jasan konsenzus oko upotrebe velikoga početnoga slova kod naziva položaja ili titula, posebice u nazivima vrhovnih poglavara države. Tako Anić-Silićev pravopis (2001) navodi da se opće imenice koje znače položaj, titulu ili zanimanje u hrvatskome pišu malim početnim slovom, bilo da stoje pred imenom ili samostalno:

(15) gospodin, gospođa, predsjednik/ca, ravnatelj/ica.

Babić-Mogušev pravopis (2011) dijeli to pravilo na dvije vrste zvanja. Prva su nazivi predsjednika i drugih visokih dužnosnika upravnih, administrativnih, političkih, ideoloških, crkvenih, vjerskih i drugih tijela koji se pišu malim početnim slovom, kao i sve druge titule:

(16) ministar, savjetnik, načelnik.

Druga su vrsta zvanja nazivi vrhovnih poglavara država i vjerskih zajednica koji se pišu velikim početnim slovom kada poslije njih ne slijedi osobno ime: (17) Papa, Kraljica, Predsjednica.

S druge strane, Matičin pravopis (2008) navodi da se nazivi vrhovnih poglavara pišu malim početnim slovom i onda kad se uz njih ne piše osobno ime:

(18) predsjednik, papa, kralj.

Pravopis IHJJ (2013) u tom smislu nudi kompromisno rješenje pa navodi da se malim početnim slovom pišu svi nazivi službenih dužnosti, kao primjer 
u (19), a velikim početnim slovom pišu se nazivi vrhovnih poglavara koji dolaze bez imena kad im se želi izraziti posebno poštovanje ili počast, kao primjer u (20):

(19) ministar, papa, predsjednica, ravnatelj

(20) Kralj, Predsjednik.

Od ostalih iznimaka $u$ pisanju velikoga početnog slova koje vrijedi navesti za poslovno dopisivanje, spomenut će se pisanje većih dijelova teksta, npr. naslova velikim slovima. Tada se radi bolje uočljivosti u tekstu cijeli naslov može napisati velikim slovima, tj. verzalom, iz estetskih, reklamnih, promidžbenih i drugih razloga. Također se u osobitim namjenama pisane riječi velikim slovima može napisati čitav tekst, dio teksta ili gdjekoje riječi u tekstu (Babić-Mogušev pravopis, 2011). Naposljetku, Matičin pravopis (2008) navodi da se u posebnim tipovima tekstova (npr. reklamnim) velika i mala početna slova rabe prilično slobodno, a takva uporaba ne podliježe pravopisnim, već grafostilističkim zahtjevima.

\subsection{Sličnosti i razlike u upotrebi posebnih tipova slova u hrvatskome $i$ engleskome jeziku}

Posebni tipovi slova služe za isticanje pojedinih dijelova teksta, a njihova upotreba određena je i pravilima pojedinih struka. Pravopis IHJJ (2013) razlikuje razmaknuta, velika, podebljana i kosa slova. $\mathrm{S}$ obzirom na to da se u službenom dopisivanju za naglašavanje teksta najčešće koriste kosa i podebljana slova, u tablicama 2 i 3 usporedit će se pravopisna pravila koja vrijede za navedene vrste slova $u$ hrvatskome i engleskome jeziku.

Tablica 2. Upotreba kosih slova u tekstu - hrvatski i engleski jezik

\begin{tabular}{|l|l|l|}
\hline Pravopisna pravila & Hrvatski jezik & Engleski jezik \\
\hline $\begin{array}{l}\text { 1. Pravopisno neprilagođene } \\
\text { strane riječi }\end{array}$ & $\begin{array}{l}\text { Kada se arhivisti pridržavaju } \\
\text { načela total archives.... }\end{array}$ & $\begin{array}{l}\text { The word for cat in Spanish } \\
\text { is gato. }\end{array}$ \\
\hline $\begin{array}{l}\text { 2. Nazivi živih bića na } \\
\text { latinskome jeziku }\end{array}$ & $\begin{array}{l}\text { Gljiva Gibberella circinata } \\
\text { uzročnik je... }\end{array}$ & $\begin{array}{l}\text { Nyssa silvatica is a medium- } \\
\text { sized tree... }\end{array}$ \\
\hline 3. Znakovi fizičkih veličina & vrijeme $t$ & Physical time $t^{\sim}$ in the text... \\
\hline $\begin{array}{l}\text { 4. Primjeri u rečenicama } \\
\begin{array}{l}\text { 5. Umjesto navodnika za nazive } \\
\text { književnoumjetničkih djela }\end{array}\end{array}$ & Imenica srce srednjega je roda. & $\begin{array}{l}\text { The noun heart can be } \\
\text { countable or uncountable. }\end{array}$ \\
\hline
\end{tabular}

Ta kratka usporedba temeljnih pravila o upotrebi kosih slova ili italic(s) ${ }^{4}$ u hrvatskome i engleskome jeziku pokazuje visok postotak sličnosti u načinu upotrebe kosih slova u oba jezika. Iznimka se javlja pri navođenju primjera u rečenicama gdje u engleskome jeziku ipak prevladava upotreba podebljanih

${ }^{4}$ Oblik italic u jednini upotrebljava se u Velikoj Britaniji, dok se množinski oblik italics uvriježio u SAD-u, Kanadi i Australiji (Peters, 2004). 
slova, posebice u tekstovima na američko-engleskoj inačici (CMS, 2010; OED, 2019; Peters, 2004).

Pregledom prethodno navedenih jezičnih vodiča na engleskome jeziku može se štoviše ustvrditi da izvorni govornici engleskoga nerijetko običavaju rabiti kosa slova za isticanje određenih riječi u rečenici ovisno o kontekstu te kako bi privukli pozornost čitatelja na određene arhaizme, neologizme ili čak neprilične izraze. Jednako tako, proširena je upotreba kosih slova za isticanje stručnoga i tehničkoga nazivlja kod prvoga navođenja u tekstu (Peters, 2004). U hrvatskome se također mogu javiti primjeri rabljenja kosih slova za različite sintaktičke potrebe, za označavanje rečeničnoga naglaska ili isticanje pojedinih dijelova, a katkada i cijele rečenice, kako se navodi u Babić-Moguševu pravopisu (2011).

O neobvezatnoj uporabi kosih slova daje se napomena u Pravopisu IHJJ (2013) pri označavanju imena zakona, propisa, uredaba, pravilnika, odluka, rješenja, norma itd. Naglašeno je da uporaba kosih slova u tom slučaju nije obvezatna jer takav način označavanja nije uobičajen $u$ administrativnoj praksi.

Tablica 3. Upotreba podebljanih slova u tekstu - hrvatski i engleski jezik

\begin{tabular}{|l|l|l|}
\hline Pravopisna pravila & Hrvatski jezik & Engleski jezik \\
\hline 1. Ključne riječi u tekstu & $\begin{array}{l}\text { Nagrada Bernardo Bernardi za } \\
\text { najuspješnije ostvarenje... }\end{array}$ & $\begin{array}{l}\text { The Man Booker Prize was } \\
\text { awarded to Hilary Mantel... }\end{array}$ \\
\hline $\begin{array}{l}\text { 2. Naslovi i podnaslovi } \\
\begin{array}{l}\text { 3. Rječnički ili enciklopedijski } \\
\text { unos }\end{array}\end{array}$ & Uvod u neurolingvistiku & $\begin{array}{l}\text { Introduction to } \\
\text { Neurolinguistics }\end{array}$ \\
\hline 4. Upućivanje u tekstu & prema uputama iz Priloga 4. & $\begin{array}{l}\text { abbreviation } \\
\text { Terminology for Europe) }\end{array}$ \\
\hline
\end{tabular}

Pravopis IHJJ (2013) navodi da se podebljana slova upotrebljavaju rjeđe od kosih te se mogu javiti u tekstu u svrhu isticanja, ako su kosa slova već upotrijebljena s drugom svrhom, primjerice za pisanje stranih riječi i sl. Načini rabljenja podebljanih slova gotovo se u cijelosti poklapaju s engleskom praksom. U engleskome se jeziku podebljana slova ili bold type (OED, 2019) također javljaju rjeđe te ih jezični priručnici (CMS, 2010; OSM, 2003; Peters, 2004) ne stavljaju na prvo mjesto za isticanje u tekstu, već prednost daju kosim ili čak podcrtanim slovima u tiskanom pismu. Razlog je opće uvjerenje da podebljana slova vizualno ometaju čitatelja pa se savjetuje ograničena i promišljena upotreba. 


\section{ANALIZA PRIMJERA U SLUŽBENIM TEKSTOVIMA}

Druga razina kontrastivne analize obuhvaća usporedbu primjera upotrebe velikoga početnog i posebnih tipova slova $u$ službenim tekstovima na hrvatskome i engleskome jeziku.

\subsection{Rezultati usporedbe primjera upotrebe velikoga početnog slova u hrvatskome i engleskome jeziku}

Nakon rezultata usporedbe primjera iz tablice 4, slijedi rasprava o sličnostima i razlikama te mogućim odstupanjima od pravopisnih pravila u načinu upotrebe hrvatskih i engleskih primjera.

Tablica 4. Upotreba velikoga početnog slova u službenim tekstovima

\begin{tabular}{|c|c|c|}
\hline Br. & Primjeri upotrebe - hrvatski jezik & Primjeri upotrebe - engleski jezik \\
\hline 1. & $\begin{array}{l}\text {...temeljem Informacije o sudjelovanju } \\
\text { MVEP RH u Europskom diplomatskom } \\
\text { programu. }\end{array}$ & $\begin{array}{l}\text {...on the basis of the information* }{ }^{*} \text { provided } \\
\text { by our legal team... }\end{array}$ \\
\hline 2. & $\begin{array}{l}\text { U prilogu Vam dostavljamo obrazac Izvješća } \\
\text { o radu... }\end{array}$ & Please send this appraisal report ${ }^{*} \ldots$ \\
\hline 3. & Poštovani Ministre... & Dear Minister... \\
\hline 4. & $\begin{array}{l}\text {...dokumentacija je proslijeđena u Vaše } \\
\text { Ministarstvo... }\end{array}$ & .... and the Ministry is at the disposal... \\
\hline 5. & $\begin{array}{l}\text {...o nastavku sudjelovanja u navedenoj } \\
\text { Misiji. }\end{array}$ & The Mission responded positively... \\
\hline 6. & ...na priloženi Nacrt nismo imali primjedbi. & I am pleased to send you the draft* agenda... \\
\hline 7. & $\begin{array}{l}\text {...koji je obnašao funkciju Načelnika dvije } \\
\text { godine. }\end{array}$ & $\begin{array}{l}\text {...who was the Head of the Programme } \\
\text { Office... }\end{array}$ \\
\hline 8. & ...molimo da proslijedite tekst Natječaja... & $\begin{array}{l}\text { I would be grateful if you could forward this } \\
\text { Call to the relevant national administrations. }\end{array}$ \\
\hline 9. & U Odjelu je obavljena primopredaja... & $\begin{array}{l}\text {...on topics of interest for the Department's } \\
\text { staff... }\end{array}$ \\
\hline 10. & $\begin{array}{l}\text {.... k konačnu Odluku donosi čelnik državnog } \\
\text { tijela. }\end{array}$ & $\begin{array}{l}\begin{array}{l}\text { This Decision should set out all the } \\
\text { conditions... }\end{array} \\
\end{array}$ \\
\hline 11. & $\begin{array}{l}\text {...prema Planu zapošljavanja hrvatskih } \\
\text { državljana u EU institucijama... }\end{array}$ & $\begin{array}{l}\text {...the new employment plan* has been made } \\
\text { according to... }\end{array}$ \\
\hline 12. & $\begin{array}{l}\text { Potrebno je osnovati novo Povjerenstvo za } \\
\text { predizbor... }\end{array}$ & Afterwards, the Panel will write a report... \\
\hline 13. & $\begin{array}{l}\text { Proučivši gore navedeni Pravilnik došli smo } \\
\text { do sljedećih zaključaka... }\end{array}$ & $\begin{array}{l}\text { The persons covered by these Rules must } \\
\text { have worked... }\end{array}$ \\
\hline 14. & $\begin{array}{l}\text { Nakon sastanka s Predsjednicom } \\
\text { povjerenstva... }\end{array}$ & $\begin{array}{l}\text {...the President is responsible for ensuring } \\
\text { that the committee... }\end{array}$ \\
\hline 15. & $\begin{array}{l}\text { Nije prihvaćena primjedba da se u Prijedlogu } \\
\text { zakona... }\end{array}$ & The Bill will amend a number of Acts... \\
\hline 16. & $\begin{array}{l}\text { Ovaj Program je koristan zbog stjecanja } \\
\text { iskustva u radu... }\end{array}$ & $\begin{array}{l}\text { The aim of the programme* is to enable } \\
\text { young people... }\end{array}$ \\
\hline 17. & ...šaljemo predmetnu Promemoriju... & Please find attached the memo*... \\
\hline 18. & $\begin{array}{l}\text {...sukladnu naputku Savjetnice u Kabinetu } \\
\text { ministra... }\end{array}$ & $\begin{array}{l}\text { Dear Counsellor, } \\
\text { Please find below the revised quota for } 2019 .\end{array}$ \\
\hline
\end{tabular}




\begin{tabular}{|c|c|c|}
\hline 19. & ...prijedlozi stajališta navedenog Sektora... & ....as the Sector brought suggestions... \\
\hline 20. & ...u Službu je dostavljen tekst ugovora... & $\begin{array}{l}\text {...text related to the field of competence of } \\
\text { the Division... }\end{array}$ \\
\hline 21. & ...za vrijeme trajanja ovog Sporazuma... & $\begin{array}{l}\text {...during the Agreement with the } \\
\text { Commission... }\end{array}$ \\
\hline 22. & $\begin{array}{l}\begin{array}{l}\text { Sukladno Strategiji, glavni koordinacijski } \\
\text { mehanizam njene provedbe ... }\end{array} \\
\end{array}$ & $\begin{array}{l}\text {...entering into force of the EU Global } \\
\text { Strategy* (EUGS) }\end{array}$ \\
\hline 23. & Taj se zahtjev također prilaže Upitniku... & $\begin{array}{l}\text { Please submit the completed } \\
\text { Questionnaire... }\end{array}$ \\
\hline 24. & $\begin{array}{l}\text {... odnosno koordinacija nadležnih Uprava } \\
\text { ministarstva... }\end{array}$ & $\begin{array}{l}\text { The following departments have been } \\
\text { formed within the Directorate:... }\end{array}$ \\
\hline 25. & $\begin{array}{l}\text { Ovom Uredbom uređuje se postupak i način } \\
\text { raspisivanja... }\end{array}$ & $\begin{array}{l}\text { This Regulation is applicable in all Member } \\
\text { States... }\end{array}$ \\
\hline
\end{tabular}

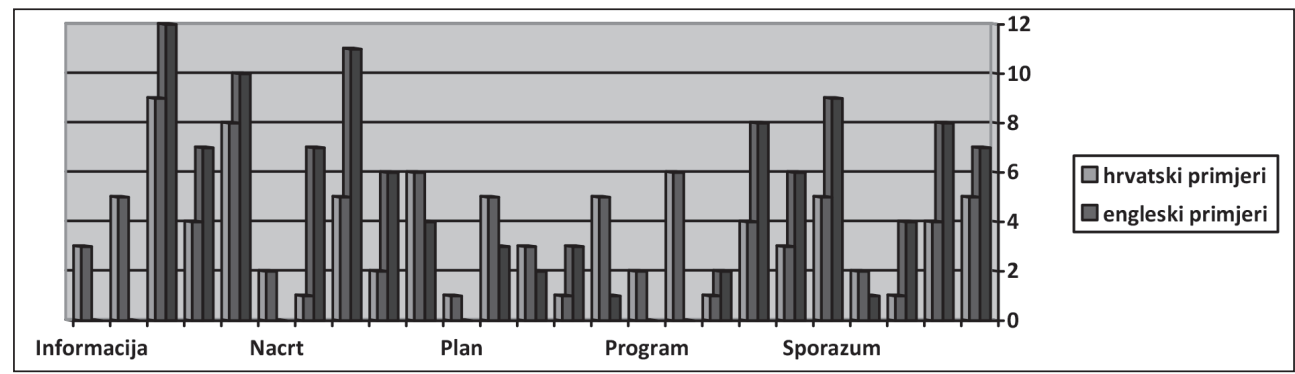

Grafikon 1. Broj pronađenih primjera upotrebe velikoga početnog slova u službenim tekstovima na hrvatskome i engleskome jeziku

Navedeni rezultati analize prikupljenih primjera pokazuju da se veliko početno slovo u službenim tekstovima na hrvatskome jeziku upotrebljava $\mathrm{u}$ devedeset posto slučajeva sukladno pravopisnim pravilima. Iznimku predstavljaju primjeri imenica ministar, načelnik, predsjednica i savjetnica kod kojih je zanemareno pravilo da se opće imenice koje znače položaj, titulu ili zanimanje pišu malim početnim slovom, bilo da stoje pred imenom ili samostalno. Ovdje se može raspraviti o dva moguća razloga toj pojavi. Uzme li se u obzir da su navedeni primjeri u službenoj komunikaciji na engleskome jeziku također napisani velikim početnim slovom, postavlja se pitanje o utjecaju engleskoga jezika na pravopisno pravilo. Utjecaj je djelomično opravdan ako se radi o izravnim prijevodima raznih službenih dokumenata s engleskoga na hrvatski jezik, primjerice tekstova natječaja i sličnoga gdje se preuzima englesko pravilo o pisanju naziva službenih položaja. ${ }^{5}$ Međutim, kod znatnog broja službenih dopisa, poglavito onih koje građani upućuju visokopozicioniranim djelatnicima državne uprave, riječ je o svojevrsnom

\footnotetext{
${ }^{5} \mathrm{O}$ problemu preuzimanja engleskih pravopisnih pravila $\mathrm{u}$ hrvatski jezik također raspravlja Mihaljević (2018: 159-163) u radu na istraživačkome projektu Hrvatski mrežni rječnik - Mrežnik (IP -2016-06-2141).
} 
iskazivanju poštovanja osobama na položajima moći, što je podjednako važno i u području diplomacije.

Osim te zamijećene iznimke u pisanju velikoga početnog slova, analiza je dala još nekoliko neočekivanih rezultata. Naime, u slučaju pisanja skraćenih imena dokumenata, koji su u primjerima na hrvatskome napisani sukladno pravopisnom pravilu o velikome početnom slovu, za engleske primjere također se krenulo od dvije pretpostavke. Prva je uvriježena percepcija da se u engleskome jeziku češće javljaju velika početna slova nego u hrvatskome, a druga je pretpostavka da će se u engleskim primjerima doslovno primijeniti englesko pravopisno pravilo o pisanju naziva dokumenata. Razlika je zabilježena kod sedam primjera označenih zvjezdicom u gornjoj tablici: information, report, draft, plan, programme, memo i strategy. Pomnijim uvidom u kontekst službenih pismena pronađen je samo jedan slučaj kada je imenica strategy bila napisana velikim početnim slovom, kao što je to navedeno $\mathrm{u}$ primjeru EU Global Strategy.

Dakle za razliku od hrvatskoga gdje se primjeri općih imenica informacija, izvješće, nacrt, plan, prijedlog i promemorija, kao dio višečlanoga naziva službenog dokumenta, javljaju samostalno u rečenicama i pišu velikim početnim slovom, može se primijetiti da u engleskoj administrativnoj praksi skraćeni oblik naziva nekog dokumenta nerijetko predstavljaju dvije ili tri riječi u svezi, pri čemu je potrebno naglasiti da se sve riječi u svezi pišu velikim početnim slovom.

Uspoređujući nadalje hrvatske i engleske primjere, nameće se semantičko pitanje o tome što predstavlja naziv službenog dokumenta i tko, u stvari, odlučuje da će neki tekst dobiti službeni naziv koji će se zatim pisati velikim slovom.

Iz analize je namjerno izostavljen primjer imenice zakon jer se predmnijeva da kod njezine upotrebe, $\mathrm{u}$ smislu punog naziva određenog zakona, nema nikakve dvojbe da će se u slučaju samostalnog pojavljivanja u tekstu pisati velikim početnim slovom. Slično je doduše i s imenicama uredba, strategija ili pak sporazum jer se radi o podzakonskim aktima koje donose visoka upravna tijela. Međutim, kod primjera imenica kao što su informacija, nacrt, plan ili promemorija iz konteksta je razvidno da se odnose na tekstove koji nastaju unutar manjih organizacijskih jedinica državnih tijela za potrebe ograničenog broja korisnika.

U tom smislu, realno je pretpostaviti da su autori službenih pismena pri samostalnom navođenju tih imenica kao referenci na puni naziv ili naslov određenog teksta htjeli naglasiti njihovu važnost u specifičnom kontekstu administrativno-diplomatskog područja te su ih zato pisali velikim početnim slovom. Jednako tako, kod prethodno navedenih engleskih primjera imenica koje su napisane malim početnim slovom, može se pretpostaviti da je razlog tomu, iako se radi o službenim dokumentima, činjenica da za autore teksta ne predstavljaju posebno važne dokumente da bi ih pisali velikim početnim slovom. 
Cjelovita je pak analiza primjera pokazala da se veliko početno slovo ne rabi u postotku iznad trideset posto u svrhu isticanja, kao što je bila početna pretpostavka. Od ukupno 93 primjera imenica, za koje je pregledom građe utvrđeno da su napisani velikim početnim slovom, primjera isticanja bilo je 24. Nadalje je utvrđeno da su primjeri isticanja izrazito kontekstno osjetljivi te upućuju na namjeru govornika za iskazivanjem poštovanja nekoj službenoj osobi ili za pridavanjem važnosti određenom službenom tekstu. Stoga su u daljnju analizu uključeni posebni tipovi slova kod kojih je vidljivija namjera isticanja pojedinih riječi ili rečeničnih cjelina u službenom dopisivanju, kao što će se oprimjeriti u sljedećem potpoglavlju.

\subsection{Rezultati usporedbe primjera upotrebe posebnih tipova slova $u$ hroatskome i engleskome jeziku}

Za potrebe rada, $\mathrm{u}$ tablici 5 izdvojeni su reprezentativni primjeri u hrvatskim i engleskim službenim tekstovima sukladno kriteriju čestotnosti pojavljivanja i pravopisnim pravilima upotrebe. Kao i pri odabiru primjera s velikim početnim slovom na engleskome, prednost je dana engleskim primjerima posebnih tipova slova koji su se nalazili u bliskom značenjskom kontekstu u usporedbi s primjerima na hrvatskome jeziku.

Tablica 5. Upotreba kosih i podebljanih slova u službenim tekstovima

\begin{tabular}{|c|c|c|}
\hline Br. & Primjeri s kosim slovima na hrvatskome & Primjeri s kosim slovima na engleskome \\
\hline 1. & - obavijest (odgovor, dopis...), dostavlja se & Email Notifications \\
\hline 2. & - suglasnost, daje se & On behalf of... \\
\hline 3. & Ciljevi:.......Vremenski okvir:......... & Aims and Objectives \\
\hline 4. & Prilog: Program seminara ... & $($ Title $) \ldots . . . . .($ Name $) \ldots . . . . .($ Surname $) \ldots . .$. \\
\hline 5. & cost-free, co-financing, temporary agent, roster... & in the form of a posteriori reimbursement \\
\hline 6. & $\begin{array}{l}\text { U Bruxellesu je 18. listopada 2016. održan } 6 . \\
\text { sastanak... }\end{array}$ & $\begin{array}{l}\text { "These allowances are intended to cover SNEs' } \\
\text { living expenses..." }\end{array}$ \\
\hline 7. & Napomena: riječ je o mjestu srednje razine (AD 9) & $\begin{array}{l}\text { This is a paper intended for a specific community } \\
\text { of recipients. }\end{array}$ \\
\hline Br. & $\begin{array}{l}\text { Primjeri s podebljanim slovima na } \\
\text { hrvatskome }\end{array}$ & $\begin{array}{l}\text { Primjeri s podebljanim slovima na } \\
\text { engleskome }\end{array}$ \\
\hline 1. & $\begin{array}{l}\text { Adresat npr. Stalno predstavništvo RH pri } \\
\text { Vijeću Europe }\end{array}$ & $\begin{array}{l}\text { BA Budget and administration } \\
\text { BA.HR.3 Rights and obligations }\end{array}$ \\
\hline 2. & Predmet: Nacrt Sporazuma... & $\begin{array}{l}\text { Agenda, Subject: EVACUATION } \\
\text { PROCEDURES- exchange of views }\end{array}$ \\
\hline 3. & Potpisnik npr. Glavna tajnica & Head of Division \\
\hline 4. & Datum npr. Zagreb, 12. ožujka 2019. & by Friday 13 April 2018 at the latest \\
\hline 5. & $\begin{array}{l}\text { Sažetak: Dana 14. ožujka 2017. održan je } \\
\text { Seminar... }\end{array}$ & $\begin{array}{l}\text { Summary overview: There are } 11 \\
\text { international mission members... }\end{array}$ \\
\hline 6. & $\begin{array}{l}\text {...status SNE reguliran je Odlukom } \\
\text { Europske komisije... }\end{array}$ & $\begin{array}{l}\text { A good application is tailored to the specific } \\
\text { position... }\end{array}$ \\
\hline 7. & Prilog: Dva (2) primjerka Sporazuma & Attached application form (annex 3) \\
\hline
\end{tabular}




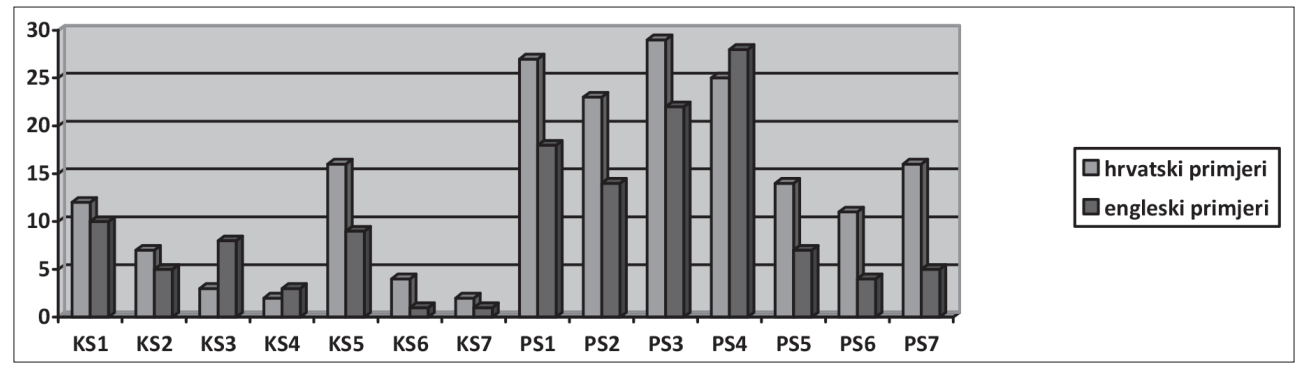

Grafikon 2. Broj pronađenih primjera upotrebe kosih slova (KS) i podebljanih slova (PS) u službenim tekstovima na hrvatskome i engleskome jeziku

Pregled primjera upotrebe posebnih tipova slova u službenim dopisima, bilješkama i obavijestima pokazuje nešto širi opseg upotrebe od onoga koji je zadan i normiran pravopisnim pravilima. Od ukupnog broja od 46 pronađenih primjera kosih slova, samo je za 16 primjera utvrđeno da su napisani sukladno pravilu o pisanju pravopisno neprilagođenih stranih riječi. Međutim, može se ustvrditi da je taj postotak razmjerno visok, između ostaloga, i zbog toga što suvremeni poslovni rječnik obiluje izrazima i nazivima koji se iz raznih razloga ne prevode na hrvatski jezik.

Kosa slova također se rabe za isticanje pojedinih dijelova dopisa gdje se primatelju želi skrenuti pozornost na vrstu i svrhu dopisa, vremenski okvir u kojem je potrebno nešto obaviti, određene napomene, kao i potrebne priloge. Zabilježena su i 4 slučaja u službenim bilješkama gdje su veće rečenične cjeline bile napisane kosim slovima kao sažetak koji primatelju teksta može pomoći da brzo stekne ideju o najvažnijim podacima iz službenog pismena.

Nešto manji broj engleskih primjera upotrebe kosih slova (ukupno je pronađeno 37) u odnosu na hrvatski, ukazuje na moguće razlike u načinu upotrebe, jer je zabilježen samo jedan slučaj među engleskim primjerima gdje su kosa slova upotrijebljena za isticanje velikih rečeničnih cjelina. Primjetno je da se u engleskome kosa slova upotrebljavaju za isticanje navoda, pri čemu će se rabiti i navodni znakovi, a u službenim bilješkama na engleskome pronađeno je osam primjera gdje se kosa slova upotrebljavaju za isticanje podnaslova.

Za razliku od kosih slova, u hrvatskom dijelu građe pronađeno je ukupno 145 primjera upotrebe podebljanih slova, unatoč savjetima u pravopisnim priručnicima o ograničenoj upotrebi u svrhu isticanja riječi i rečeničnih skupova. Primjeri iz hrvatske administrativne prakse ukazuju na namjeru autora službenih pismena da se istaknu dijelovi dopisa u kojima se navodi adresa primatelja, predmet dopisa, titula i ime potpisnika, datum nastanka dopisa te broj i vrsta priloga koji idu uz dopis.

Što se tiče službenih bilježaka, primjetan je porast upotrebe podebljanih slova za naglašavanje određenih rečeničnih cjelina. Razlog tomu možda se 
može pronaći u načinu i brzini službene komunikacije, a s obzirom na to da svakodnevno nastaje velik broj bilježaka, njihovim autorima izuzetno je važno prenijeti ključne informacije vezane uz određenu temu. Kako bi primateljima obavijesti olakšali snalaženje $u$ većim tekstnim cjelinama, pošiljatelji uz pomoć podebljanih slova ističu dio teksta koji obavijesno nosi veću važnost. Ovdje se ponovo može raspravljati koliko je utjecaj engleskoga jezika na suvremenu hrvatsku poslovnu komunikaciju pridonio porastu upotrebe podebljanih slova. Jedina poveznica na kojoj se može temeljiti ta pretpostavka odnosi se na čestotnost uporabe podebljanih slova u gotovo svim oblicima službenih tekstova na engleskome jeziku.

Naime, nakon pregleda engleske građe, razvidno je da je u službenim tekstovima i poslovnoj prepisci raznih institucija Europske unije i ostalih međunarodnih organizacija češća upotreba podebljanih (98 pronađenih primjera) nego kosih slova u svrhu naglašavanja dijelova rečenica i većih rečeničnih cjelina. Koliko je popularnost takvog oblika naglašavanja teksta utjecala na službeni pisani diskurs hrvatskih državnih i ostalih javnih tijela i institucija, može biti predmetom istraživanja u budućim radovima na temu administrativnoga funkcionalnog stila.

\section{ZAKLJUČAK}

U radu se nastojalo ukazati na određene grafemske mogućnosti u slučajevima službene pisane komunikacije kada autori tekstova žele istaknuti pojedine riječi i rečenice kako bi primateljima skrenuli pozornost na njihovu važnost. Za potrebe analize, grafem je izjednačen sa slovom te je sukladno tomu provedena dvorazinska kontrastivna analiza upotrebe velikoga početnog i dvije vrste posebnih tipova slova (kosih i podebljanih) u hrvatskome i engleskome jeziku.

Prvom razinom analize, koja je provedena supostavljanjem normiranih oblika upotrebe velikoga početnog, kosih i podebljanih slova u oba jezika, dobiven je sustavan prikaz njihovih sličnosti i razlika u okviru pravila važnih za administrativni funkcionalni stil.

Drugom razinom kontrastivne analize željela se provjeriti pretpostavka da će se $u$ pojedinim segmentima administrativnoga stila javiti određena odstupanja od norme, čime se htjelo dokazati da se pravopisna pravila mogu prilagoditi suvremenim zahtjevima brzog prijenosa podataka u službenim oblicima komunikacije i namjerama pošiljatelja da istaknu obavijesno važne dijelove teksta.

Pritom se krenulo od još jedne pretpostavke, a to je da se navedena odstupanja javljaju, između ostaloga, zbog rastućeg utjecaja engleskoga na obilježja hrvatskoga poslovnog stila, posebice s ulaskom Republike Hrvatske u Europsku uniju. 
Ponajprije se to odnosilo na slučajeve zabilježene u službenim dopisima na hrvatskome prema različitim državnim tijelima Republike Hrvatske, kada su se opće imenice koje označavaju položaj, titulu ili zanimanje pisale, suprotno pravopisnoj normi, velikim početnim slovom, kao što je to primjerice pravilo u engleskome jeziku. Iako se jednim dijelom može govoriti o izravnom prijevodu naziva nekog položaja iz engleskoga, ipak valja uzeti u obzir specifičnost konteksta administrativnoga podstila $u$ kojem autori dopisa žele iskazati počast više rangiranim djelatnicima, a to je najjednostavnije postići uporabom velikoga početnog slova. Da je kontekst nastanka službenih pismena izrazito važan za odabir velikoga početnoga slova, pokazali su primjeri naziva određenih dokumenata kada se prva riječ naziva samostalno pojavljivala $u$ tekstu. Potrebno je naglasiti da se $u$ tim slučajevima u hrvatskome jeziku nije radilo samo o poštivanju pravopisnih pravila jer nazivi tekstova nisu uvijek imali pravnu ili zakonodavnu snagu službenog akta, već su autori, iz razloga vezanih uz posebna obilježja pojedinoga administrativnog konteksta, željeli naglasiti trenutačnu važnost teksta na koji su se referirali. S druge strane, u engleskome jeziku pojedini nazivi dokumenata bili su, suprotno očekivanjima, napisani malim početnim slovom. Međutim, takvi primjeri nisu nastali zbog nepoštivanja pravopisnih pravila jer u engleskome skraćeni naziv dokumenta, za razliku od hrvatskoga, nerijetko obuhvaća sveze dvije ili tri riječi pri čemu se sve riječi pišu velikim početnim slovom. Usporedbom konteksta da se zaključiti kako je, kao i u slučaju nastanka hrvatskih službenih pismena, bilo važno osnovno određenje dokumenata na koje su se autori referirali te im nisu pridavali takvu važnost da bi ih pisali velikim početnim slovom.

Budući da je druga razina analize upotrebe velikog početnog slova pokazala veliku kontekstnu osjetljivost na temelju koje se ne mogu izvući jasni i nedvosmisleni zaključci o upotrebi tog tipa slova u svrhu naglašavanja određenih riječi, $u$ analizu su dodatno uključeni primjeri upotrebe kosih i podebljanih slova u službenim dopisima i bilješkama.

Pregledom hrvatske i engleske službene građe zamijećen je određeni stupanj sličnosti u načinu upotrebe kosih i podebljanih slova te je nedvojbeno utvrđeno da se oba tipa slova rabe za isticanje pojedinih riječi i rečenica te katkada za naglašavanje većih rečeničnih cjelina. Također je u oba jezika uočen porast upotrebe podebljanih slova, posebice u službenim bilješkama većega opsega, što se može tumačiti namjerom pošiljatelja da primateljima olakšaju snalaženje $u$ tekstu te da im na brz i praktičan način prenesu najvažnije podatke.

Zaključno, radom se nastojalo ponuditi neka od mogućih rješenja u slučajevima službene komunikacije kada pisani oblik zamjenjuje govorni te se žele istaknuti obavijesno vrijedni dijelovi teksta. Grafemska obilježja, kao što su veličina i oblik slova, u tom smislu zadovoljavaju osnovne zahtjeve 
jezične ekonomije u abecednim sustavima pisma jer svojom univerzalnošću, jednostavnošću i mogućnošću upotrebe nastavljaju ispunjavati jezične uloge tamo gdje govoreni oblici to više ne mogu.

\section{LITERATURA}

Anić, V. i Silić, J. (2001) Pravopis hrvatskoga jezika. Zagreb: Novi Liber - Školska knjiga.

Augst, G. (1986) Descriptively and explanatorily adequate models of orthography. U Augst, G. (ur.) New trends in graphemics and orthography. Berlin: Walter de Gruyter, 25-42.

Babić, S. i dr. (2007) Glasovi i oblici hroatskoga književnog jezika: Velika hrvatska gramatika: Knjiga proa. Zagreb: Nakladni zavod Globus.

Babić, S. i Moguš, M. (2011) Hrvatski pravopis: usklađen sa zaključcima Vijeća za normu hrvatskoga standardnoga jezika. Zagreb: Školska knjiga.

Badurina, L. (2006) Hrvatska pravopisna norma u 20. stoljeću. U Hekman, J., Samardžija, M. i Pranjković I. (ur.) Hrvatski jezik u XX. stoljeću. Zbornik radova za znanstvenog skupa. Zagreb: Matica hrvatska, $145-158$.

Badurina, L. (2012) Hrvatski slovopis i pravopis u predstandardizacijskome razdoblju. U Mićanović, K. (ur.) Povijest hrvatskoga jezika / Književnost i kultura devedesetih. Zbornik radova 40. seminara Zagrebačke slavističke škole. Zagreb: Zagrebačka slavistička škola, 65-96.

Badurina, L., Marković, I. i Mićanović, K. (ur.) (2008) Hrvatski pravopis (=Matičin pravopis). Zagreb: Matica hrvatska.

Barić i dr. (2005) Hrvatska gramatika. Četvrto izdanje. Zagreb: Školska knjiga.

Baudouin de Courtenay, J. (1972) Baudouin de Courtenay anthology: Beginnings of structural linguistics. Prijevod. Stankiewicz, E. London, Bloomington: Indiana University Press.

Blagus Bartolec, G. (2017) Glagolske kolokacije u administrativnome funkcionalnom stilu. Rasprave 43(2), 285-309.

Catach, N. (1986) The grapheme: its position and its degree of autonomy with respect to the system of the language. U Augst, G. (ur.) New trends in graphemics and orthography. Berlin: Walter de Gruyter, 1-10.

Chao, Y. R. (1961) Graphic and phonetic aspects of linguistic and mathematical symbols. U Jakobson, R. (ur.) Structure of language and its mathematical aspects. Proceedings of symposia in applied mathematics (Volume XII). Washington: American Mathematical Society, 69-82.

CMS = The Chicago Manual of Style 16th Edition (2010) Chicago: The University of Chicago Press.

Ćužić, T. (2016) Funkcionalni stilovi u pravopisnome kontekstu (tekstu). Rasprave 42(2), 353-378.

Daniels, P. T. (1996) The Study of Writing Systems. U Daniels, P. T. i Bright, W. (ur.) The world's writing systems. New York: Oxford University Press.

Frančić, A., Hudeček, L. i Mihaljević, M. (2005) Normativnost $i$ višefunkcionalnost u hrvatskome standardnom jeziku. Zagreb: Hrvatska sveučilišna naklada.

Gallmann, P. (1986) The graphic elements of German written language. U Augst, G. (ur.) New trends in graphemics and orthography. Berlin: Walter de Gruyter, 43-79.

IHJJ = Hrvatski pravopis. (2013) Ur. Jozić, Ž. i dr. Zagreb: Institut za hrvatski jezik i jezikoslovlje.

James, C. (1980) Contrastive analysis. London: Longman.

Jelaska, Z. (2004) Fonološki opisi hrvatskoga jezika: Glasovi, slogovi, naglasci. Zagreb: Hrvatska sveučilišna naklada.

Jelaska, Z. i Musulin, M. (2011) Slovo i slovopis španjolskoga i hrvatskoga jezika. Lahor 12, 211-239.

Kovačević, M.i Badurina, L. (2001) Raslojavanje jezične stvarnosti. Rijeka: Izdavački centar Rijeka.

Marković, I. (2014) Hrvatska fonetika i fonologija. Skripta, https://omega.ffzg.hr/

Marković, I. (2015) O grafemu i hrvatskoj abecedi. Filologija 65, 77-112.

McAteer, E. (1992) Typeface emphasis and information focus in written language. Applied Cognitive Psychology 6 (4), 345-359.

Mesaroš, F. (1971) Grafička enciklopedija. Zagreb: Tehnička knjiga. 
Mihaljević, M. (1991) Generationa i leksička fonologija. Zagreb: Školska knjiga.

Mihaljević, M. (2018) Funkcionalni pravopis: Pravopisni problemi u hrvatskome poslovnom jeziku. III. međunarodna konferencija Od teorije do prakse u jeziku struke. Zagreb.

Musulin, M. (2011) Grafem kao višeznačnica. Lahor 12, 240-247.

OED = The Oxford English Dictionary. 2019. URL: http://www.oed.com

Ritter, R. M. (ur.) (2003). OSM = The Oxford Style Manual. Oxford: Oxford University Press.

Peters, P. (2004) The Cambridge Guide to English Usage. New York: Cambridge University Press.

Pulgram, E. (1976) The typologies of writing systems. U Haas, W. (ur.) Writing without letters. Manchester: Manchester University Press, 1-28.

Silić, J. i Pranjković, I. (2005) Gramatika hrvatskoga jezika za gimnazije i visoka učilišta. Zagreb: Školska knjiga.

Težak, S. i Babić, J. (2007) Gramatika hrvatskoga jezika: priručnik za osnovno jezično obrazovanje. Zagreb: Školska knjiga.

Turk, M. (1992) Fonologija hrvatskoga jezika (raspodjela fonema). Rijeka - Varaždin: Izdavački centar Rijeka -Tiskara Varaždin.

\section{ON GRAPHEME FEATURES THROUGH THE USE OF CAPITAL LETTERS, ITALICS AND BOLD TYPE IN THE OFFICIAL CORRESPONDENCE}

An overview of articles covering the research on grapheme features has shown the diversity of approaches to the very notion of grapheme, which often hampers its complete and clear definition. In this paper the features of the grapheme are terminologically equivalent to those of the alphabet letter in order to examine the modalities through the use of capital letters, italics and bold type, where the grapheme/the letter may be the indicator of the sender's aims in the official written discourse. The research corpus included official letters and memos and a two-level contrastive analysis has been conducted using the examples in both Croatian and English. The first level of analysis identified the similarities and the differences between the standardized forms of use of the given letters in both languages, after which their systematized representation served as a starting point for testing the thesis that the occasional deviations from the orthographic norm would appear due to the influence of the English language in the official correspondence. However, the second level of the analysis has discovered that these deviations mostly depend on the context and the aims of the authors to highlight certain parts of the text. Thus the grapheme features, such as size and font, have been used to provide the information important for a specific area of administration in a simple and effective manner.

Keywords: grapheme, features, letters, official communication, language use 


\section{PRIVITAK 1}

\section{Pregledani dokumenti na hrvatskome jeziku}

1. Interni dopis Glavnog tajništva Ministarstva vanjskih i europskih poslova RH (u daljnjem tekstu: MVEP RH) od 24. ožujka 2016. upućen Kabinetu ministra vanjskih poslova

2. E-dopis Ministarstva uprave RH od 12. rujna 2016. upućen Glavnom tajništvu MVEP RH

3. E-dopis Državnog zavoda za statistiku od 25. rujna 2016. upućen Kabinetu ministra vanjskih poslova

4. Dopis Glavnog tajništva MVEP RH od 27. rujna 2016. upućen Stalnom predstavništvu RH pri EU u Bruxellesu

5. Interna bilješka Odjela za rad u međunarodnim organizacijama i institucijama EU od 11. studenoga 2016.

6. Zapisnik o primopredaji dokumenata unutar Službe za rad u međunarodnim organizacijama i institucijama EU Glavnom tajništva MVEP RH od 24. studenoga 2016.

7. Dopis Glavnog tajništva MVEP RH od 2. siječnja 2017. upućen Stalnom predstavništvu RH pri Vijeću Europe u Strasbourgu

8. E-dopis Glavnog tajništva MVEP RH od 24. siječnja 2017. upućen djelatnicima u statusu privremenog osoblja u Europskoj službi vanjskih poslova (EEAS)

9. E-dopis MVEP RH od 6. veljače 2017. upućen Ministarstvu branitelja RH

10. E-dopis Odjela za certifikate i sigurnosne standarde od 9. veljače 2017. upućen Odjelu za rad u međunarodnim organizacijama i institucijama EU

11. E-dopis Ureda zastupnika pred Sudom za ljudska prava u Strasbourgu od 21. veljače 2017. upućen Glavnom tajništvu MVEP RH

12. Interni dopis Odjela za rad u međunarodnim organizacijama i institucijama EU od 2. ožujka 2017. upućen Glavnom tajništvu MVEP RH

13. Dopis Glavnog tajništva MVEP RH od 6. ožujka 2017. upućen Uredu predsjednika Vlade RH

14. Bilješka „Izaslani radnici u poreznom i socijalnom sustavu“ seminar RRiF Visoke škole za financijski menadžment, Zagreb, 14. ožujka 2017.

15. Dopis Glavnog tajništva MVEP RH od 16. ožujka 2017. upućen Uredu zastupnika pred Sudom za ljudska prava u Strasbourgu

16. Interni dopis Glavnog tajništva MVEP RH od 17. ožujka 2017. upućen Kabinetu ministra vanjskih i europskih poslova $\mathrm{RH}$

17. E-dopis Ministarstva poljoprivrede od 8. lipnja 2017. upućen Glavnom tajništvu MVEP RH

18. E-dopis Ministarstva uprave od 25. veljače 2018. upućen Glavnom tajništvu MVEP RH

19. Interni dopis Uprave za multilateralu i globalna pitanja od 15. ožujka 2018. Službi za rad u međunarodnim organizacijama i institucijama EU

20. E-dopis hrvatske državljanke zaposlene u Europskoj komisiji od 29. ožujka 2018. upućen Kabinetu ministrice vanjskih i europskih poslova $\mathrm{RH}$

21. E-dopis Veleposlanstva RH u Washingtonu od 26. travnja 2018. upućen Kabinetu ministrice vanjskih i europskih poslova $\mathrm{RH}$

22. Interni dopis Uprave za Europu od 27. travnja 2018. upućen Glavnom tajništvu MVEP RH

23. E-dopis Stalnog predstavništva RH pri EU u Bruxellesu od 15. lipnja 2018. upućen Glavnom tajništvu MVEP RH

24. E-dopis Uprave za multilateralu i globalna pitanja od 19. lipnja 2018. upućen Glavnom tajništvu MVEP RH

25. E-dopis Uprave za multilateralu i globalna pitanja od 6. rujna 2018. upućen Glavnom tajništvu MVEP RH

26. E-dopis Ministarstva uprave od 17. rujna 2018. upućen Glavnom tajništvu MVEP RH

27. Bilješka sa 6. sastanka EEAS-a s predstavnicima službi za ljudske resurse država članica EU, Bruxelles, 18. listopada 2016.

28. E-dopis Službe za informacijsku sigurnost i certifikate od 4. prosinca 2018. upućen stranci

29. E-dopis Uprave za Europu od 18. prosinca 2018. upućen Glavnom tajništvu MVEP RH

30. E-dopis Ministarstva uprave od 6. ožujka 2019. upućen Glavnom tajništvu MVEP RH 
31. Dopis Glavnog tajništva MVEP RH od 12. ožujka 2019. upućen Stalnom predstavništvu RH pri EU u Bruxellesu

32. E-dopis Uprave za međunarodnopravne poslove od 8. travnja 2019. upućen Glavnom tajništvu MVEP RH

\section{Pregledani dokumenti na engleskome jeziku}

1. E-dopis Europske službe vanjskih poslova (EEAS) od 2. ožujka 2016. upućen Odjelu za rad u međunarodnim organizacijama i institucijama EU MVEP RH

2. E-dopis Službe za ljudske resurse Tajništva OESS-a u Beču od 23. travnja 2016. upućen Odjelu za rad u međunarodnim organizacijama i institucijama EU MVEP RH

3. E-dopis Europske službe vanjskih poslova (EEAS) od 10. listopada 2016. upućen Odjelu za rad u međunarodnim organizacijama i institucijama EU MVEP RH

4. E-dopis Glavnog tajništva Europske komisije od 12. listopada 2016. upućen Glavnom tajništvu MVEP RH

5. E-dopis Europske službe vanjskih poslova (EEAS) od 26. listopada 2016. upućen Odjelu za rad u međunarodnim organizacijama i institucijama EU MVEP RH

6. E-dopis Službe za ljudske resurse Tajništva OESS-a u Beču od 2. studenoga 2016. upućen Odjelu za rad u međunarodnim organizacijama i institucijama EU MVEP RH

7. E-dopis Glavnog tajništva Europske komisije od 10. studenoga 2016. upućen Glavnom tajništvu MVEP RH

8. E-dopis Europske službe vanjskih poslova (EEAS) od 9. veljače 2017. upućen Službi za rad u međunarodnim organizacijama i institucijama EU MVEP RH

9. E-dopis Službe za ljudske resurse Tajništva OESS-a u Beču od 15. veljače 2017. upućen Službi za rad u međunarodnim organizacijama i institucijama EU MVEP RH

10. E-dopis Europskog ureda za odabir osoblja (EPSO) od 21. veljače 2017. upućen Glavnom tajništvu MVEP RH

11. E-dopis Glavnog tajništva Vijeća EU od 13. svibnja 2017. upućen Glavnom tajništvu MVEP RH

12. E-dopis OESS-ove Misije u Skopju od 19. rujna 2017. upućen kao odgovor stranci

13. E-dopis Tajništva OESS-a od 29. studenoga 2017. upućen Službi za rad u međunarodnim organizacijama i institucijama EU MVEP RH

14. Obrazac uz tekst natječaja Europske agencije za kontrolu ribarenja od 30. ožujka 2018.

15. E-obavijest Uprave za vanjske poslove EP od 24. svibnja 2018. upućena Stalnom predstavništvu RH pri EU u Bruxellesu

16. E-obavijest Izvršne agencije Europskog istraživačkog vijeća (ERCEA) od 8. lipnja 2018. upućena Stalnom predstavništvu RH pri EU u Bruxellesu

17. E-dopis Europske službe za vanjske poslove EEAS od 15. lipnja 2018. upućen Službi za rad u međunarodnim organizacijama i institucijama EU MVEP RH

18. E-dopis Europske službe za vanjske poslove EEAS od 17. srpnja 2018. upućen Glavnom tajništvu MVEP RH

19. E-dopis Glavnog tajništva Vijeća EU od 25. srpnja 2018. upućen Glavnom tajništvu MVEP RH

20. E-dopis Europske službe za vanjske poslove EEAS od 22. kolovoza 2018. upućen Glavnom tajništvu MVEP RH

21. E-obavijest Europske komisije od 18. listopada 2018. upućena Stalnom predstavništvu RH pri EU u Bruxellesu

22. E-dopis Europske službe za vanjske poslove EEAS od 30. studenoga 2018. upućen Službi za rad u međunarodnim organizacijama i institucijama EU MVEP RH

23. E-dopis Službe za ljudske resurse Tajništva OESS-a u Beču od 19. prosinca 2018. upućen Službi za rad u međunarodnim organizacijama i institucijama EU MVEP RH

24. E-dopis Europskog ureda za odabir osoblja (EPSO) od 4. veljače 2019. upućen Glavnom tajništvu MVEP RH

25. E-obavijest Europske komisije od 18. veljače 2018. upućena Stalnom predstavništvu RH pri EU u Bruxellesu 
26. E-dopis Europske službe za vanjske poslove EEAS od 4. travnja 2018. upućen Službi za rad u međunarodnim organizacijama i institucijama EU MVEP RH

27. E-dopis Europske službe za vanjske poslove EEAS od 20. lipnja 2018. upućen Službi za rad u međunarodnim organizacijama i institucijama EU MVEP RH

28. E-dopis Europskog ureda za odabir osoblja (EPSO) od 9. rujna 2018. upućen Glavnom tajništvu MVEP RH

29. E-dopis Europske službe za vanjske poslove EEAS od 12. siječnja 2018. upućen Službi za rad u međunarodnim organizacijama i institucijama EU MVEP RH

30. E-dopis Glavnog tajništva Vijeća EU od 26. veljače 2019. upućen Glavnom tajništvu MVEP RH

31. E-izvještaj Tajništva OESS-a u Beču od 7. ožujka 2019. upućen Službi za rad u međunarodnim organizacijama i institucijama EU MVEP RH

32. E-dopis Europske službe za vanjske poslove EEAS od 13. ožujka 2019. upućen Službi za rad u međunarodnim organizacijama i institucijama EU MVEP RH

33. E-izvještaj Glavnog tajništva Vijeća EU od 25. ožujka 2019. upućen Glavnom tajništvu MVEP $\mathrm{RH}$

\section{PRIVITAK 2}

Pregledani dokumenti iz mrežnih izvora na hrvatskome jeziku (preuzeto 30. travnja 2019.)

1. https://www.rozp.hr/images/pdfovi/Predstavka_ministru.pdf

2. http://arhiva.pregrada.hr/dokumenti/Govor\%20gradonacelnice $\% 20-\% 20$ otvorenje $\% 20$ studija\%20sestrinstva.pdf

3. https://www.mnovine.hr/hrvatska/aktualno/ministre-hocete-li-angazirati-215-svecenika-da-nadoknade-nedostatak-4300-lijecnika/

4. https://www.sps.com.hr/obavijesti-sindikata/157-napad-na-policijske-sluzbenike-u-splitu-uvodenje-elektro-sokera-i-kazneno-pravne-zastite-policijskih-sluzbenika

5. https://www.braniteljski-portal.com/roko-mijic-otvoreno-pismo-ministru-hrvatskih-branitelja-medvedu-osjecaj-prozvanosti-i-odgovornosti-bez-razloga-jako-mi-je-poznat

6. https://nsp-muprh.eu/dopis-ministru-gosp-vlahi-orepicu/

7. http://www.057info.hr/vijesti/2016-04-05/otvoreno-pismo-ministru-nakicu-privatizacija-vec-20-godina-razara-zdravstvo

8. https://www.ps-portal.eu/2019/03/08/udruga-mladih-eks-pisala-ministru-maricu-zele-na-koristenje-vojarnu-cerkezovac/

9. https://www.samobor.hr/storage/upload/novosti/2._uputa_za_prijavitelje_125828.pdf

10. https://euribarstvo.hr/novosti/novo-objavljeni-natjecaji-za-dodjelu-potpore-u-okviru-mjere-i-8-zastita-zdravlja-i-sigurnost-i-i-20-energetska-ucinkovitost-i-ublazavanje-klimatskih-promjena/

11. https://www.unipu.hr/_news/87172/Tekst_natjecaja.pdf

12. http://medjimurska-zupanija.hr/2019/02/11/javni-natjecaj-za-sufinanciranje-programa-projekata-sportskih-udruga-medimurske-zupanije-u-2019-godini/

13. http://www.crikvenica.hr/aktualno/item/4609-natjecaj-za-dodjelu-potpore-u-okviru-mjere-i-1-inovacije

14. http://www.edubrovnik.org/natjecaji-i-pozivi/javni-natjecaj-za-financiranje-projekata-ili-programa-udruga-iz-podrucja-zastite-okolisa-i-prirode-za-2019-godinu/

15. https://mladost-sport.hr/test/wp-content/uploads/2019/02/Javni-natje\%C4\%8Daj-udruge-19. pdf

16. http://www.rugvica.hr/wp-content/uploads/2017/04/UPUTE-ZA-PRIJAVITELJE-MANIFESTACIJE-2019..pdf

Pregledani dokumenti iz mrežnih izvora na engleskome jeziku (preuzeto 3. svibnja 2019.)

1. http://ec.europa.eu/carol/?fuseaction=download\&documentId=090166e59f08b800\&title=Invitation_Mercosur.pdf

2. http://sssh.hr/upload_data/ckeditor/ETUC\%20vladi.pdf 
3. https://www.fishsec.org/app/uploads/2016/01/130827-Joint-NGO-Letter-to-Ministers-HELCOM.pdf

4. https://corporateeurope.org/sites/default/files/letter_to_german_government_from_mep.pdf

5. https://northernlgps.org/assets/pdf/2019-03-28_statguidanceresponse_addendum.pdf

6. http://www.savethehighseas.org/publicdocs/Letter-to-the-Fisheries-Minister.pdf

7. https://www.legitech.lu/newsroom/actualites/bill-7128-implementing-the-fourth-anti-money-laundering-directive/

8. http://www.javnanabava.hr/default.aspx?id=3988

9. https://www.coe.int/en/web/human-rights-rule-of-law/dgi-directorates

10. https://www.humanbrainproject.eu/en/about/governance/boards/directorate/

11. https://home.cern/news/opinion/cern/2019-open-discussion-directorate

12. https://www.isesco.org.ma/directorate-of-external-relations-and-cooperation/

13. https://ec.europa.eu/newsroom/article29/item-detail.cfm?item_id=614109

14. https://www.businesseurope.eu/policies/governance/messages-european-council 